\title{
COMPARATIVE ASSESSMENT OF RUNOFF AND ITS COMPONENTS IN TWO CATCHMENTS OF UPPER INDUS BASIN BY USING A SEMI DISTRIBUTED GLACIO- HYDROLOGICAL MODEL
}

\author{
*Syed Hammad Ali ${ }^{1,2}$, Iram Bano ${ }^{1}$, Rijan Bhakta Kayastha ${ }^{1}$, Ahuti Shrestha ${ }^{1}$ \\ ${ }^{1}$ Himalayan Cryosphere, Climate and Disaster Research Centre, Department of Environmental Science and Engineering, School of \\ Science, Kathmandu University, Dhulikhel, Nepal (rijan@ku.edu.np) (ahuti@ku.edu.np) (irambano41@ gmail.com) \\ ${ }^{2}$ Glacier Monitoring Research Centre, Water \& Power Development Authority, Pakistan (syedhammadali2001@ yahoo.com)
}

KEY WORDS: Positive degree day, climate variability, glacier coverage, water resource management, Gilgit River basin, Hunza River basin, Upper Indus Basin

\begin{abstract}
:
The hydrology of Upper Indus basin is not recognized well due to the intricacies in the climate and geography, and the scarcity of data above $5000 \mathrm{~m}$ a.s.l where most of the precipitation falls in the form of snow. The main objective of this study is to measure the contributions of different components of runoff in Upper Indus basin. To achieve this goal, the Modified positive degree day model (MPDDM) was used to simulate the runoff and investigate its components in two catchments of Upper Indus basin, Hunza and Gilgit River basins. These two catchments were selected because of their different glacier coverage, contrasting area distribution at high altitudes and significant impact on the Upper Indus River flow. The components of runoff like snow-ice melt and rainfall-base flow were identified by the model. The simulation results show that the MPDDM shows a good agreement between observed and modeled runoff of these two catchments and the effects of snow and ice are mainly reliant on the catchment characteristics and the glaciated area. For Gilgit River basin, the largest contributor to runoff is rain-base flow, whereas large contribution of snow-ice melt observed in Hunza River basin due to its large fraction of glaciated area. This research will not only contribute to the better understanding of the impacts of climate change on the hydrological response in the Upper Indus, but will also provide guidance for the development of hydropower potential and water resources assessment in these catchments.
\end{abstract}

\section{INTRODUCTION}

Pakistan is situated in South Asia between $24^{\circ}-37^{\circ} \mathrm{N}$ latitude and $66^{\circ}-77^{\circ} \mathrm{E}$. It hosts the triple point (junction) of three world famous mountain rages Himalayas, Karakoram and Hindukush in its north. There are more than 5000 glaciers feeding the Indus from 10 sub-basins through different tributaries ranging from few tens of meters to more than $70 \mathrm{~km}$ long. A major proportion of flow in the Indus River is contributed by its snow and glacier-fed river catchments situated in the Karakoram Range. The major Indus basin is divided into three basins the Kabul, Upper Indus, and Panjnad. The Upper Indus basin includes the Gilgit, Hunza, Shigar, Shyok, Zanskar, Shingo, Astor, and Upper Indus sub-basins (Bajracharya and Shrestha, 2011). These basins feature distinct hydrological regimes, which are linked with the main source (snow and glacier) of their meltwater generation and can be differentiated by its strong correlation with the climatic variables.

The hydrological system of Upper Indus basin is mainly reliant on the monsoon and melting of snow and glaciers. To know the contribution of glaciers to runoff is an essential step to identify the impact of climate change on water resources, flooding and drought in glacier fed basins. At present there are four approaches to investigate the runoff components from rainfall, melting of snow and glaciers: the water balance analysis (Thayyen et al., 2005; Kumar et al., 2007), glacier degradation from observation or modelling as contribution to runoff (Kotliakov, 1996; Kaser et al., 2010), isotopic investigations (Dahlke et al., 2013) and hydrological modelling (Hagg et al., 2007; Naz et al., 2013) though limitations of these methods cannot be ignored, especially for climate change studies. The water balance method can roughly estimate the effects of glacier and snow in monthly or larger time scale.

Approaches that relate glacier melt water production (gained by the measurements or modelling) with measured discharge further downstream are problematic because glacier melt water can be considered as raw volume input into the runoff system, but the discharge further downstream has been modified by precipitation, evaporation, irrigation, damming, or exchange with subsurface flow regimes and groundwater (Kaser et al., 2010). The isotopic investigation cannot be used extensively as it requires large financial and laboratory support. However, the application of hydrological models to understand the glacier effects in hydrology is comparatively new and more commonly used (Hagg et al., 2007; Huss et al., 2008; Koboltschnig et al., 2008; Prasch, 2010; Nepal et al., 2013). But the main problem is the availability of long term data of high quality to symbolize the hydrological dynamics of Upper Indus Basin (UIB).

The hydro-climatic conditions in glacierized basins of the UIB alter considerably with elevation and topography and the behavior of glaciers to climate changes may be dissimilar at higher elevation than lower elevation, predominantly for large glaciers where thick/thin debris cover can suppress/increase the melting rate (Hewitt, 2005, 2011; Kaab et al., 2012; Gardelle et al., 2012).

According to the findings of Archer, 2003; Fowler and Archer, 2005 and Hasson et al., 2015, the initial water supply from the UIB after a long dry period (October to March) is gained from melting of snow (late-May to late-July), the range of which largely depends upon the accumulated snow amount and concurrent temperatures and snowmelt runoff is then overlapped by the glacier melt runoff (late-June to late-August), 
the extent of which primarily be contingent to the melt season temperatures.

Climate change is explicit and increasingly serious concern due to its recent acceleration globally. Glaciers and icy surfaces are the most sensitive indicators of global warming which have shown their immediate response in terms of mass balance and contribution of melt water to the sea level rise. According to World Meteorological Organization statement on status of climate, the first decade (2001-2010) is the warmest decade recorded over the globe and 2010 ranked as the warmest year $\left(+0.53^{\circ} \mathrm{C}\right)$ followed by $2005\left(+0.52^{\circ} \mathrm{C}\right)$ and $1998\left(0.52^{\circ} \mathrm{C}\right)$. Sixteen warmest years of the globe occurred during the last two decades.

Similarly, local impacts of the regionally varying climate change can differ significantly, depending upon the local adaptive capacity, exposure and resilience (Salik et al., 2015), especially for the sectors of water, food and energy security. In view of high sensitivity of mountainous environments to climate change and the role of melt water as an important regulator for UIB runoff dynamics, it is very important to study the snow and glacier and their impacts on the hydrologic regime of this Upper Indus region under climate variability to manage the available water resources. The aim of this study is to understand the glacier and snow effects on hydrological regime in Upper Indus basin and to identify the contributions to runoff components

\section{STUDY AREA}

The Gilgit River basin with drainage area, 13,471 km² (Fig. 1), encompasses eastern part of the Hindukush Range and drains southeastward into the Indus River. Gilgit River is measured at Alam Bridge hydrometric station. Geographically the basin extends from $35.80^{\circ} \mathrm{N}, 72.53^{\circ} \mathrm{E}$ to $36.91^{\circ} \mathrm{N}, 74.70^{\circ} \mathrm{E}$. The elevation of the basin ranges from $1,250-7,730 \mathrm{~m}$ a.s.l. Approximately $982 \mathrm{~km}^{2}$ of catchment area is at an elevation above $5000 \mathrm{~m}$ and almost the same area $(8 \%)$ is glaciated accounting for $4 \%$ of the UIB cryospheric extent. The clean glacier area is $\approx 944 \mathrm{~km} 2$ and the debris cover area is $\approx 146 \mathrm{~km}^{2}$. The average SCA varies from approximately $85 \%$ in winter to $10 \%$ in summer (Tahir, et al., 2011). Gilgit River basin receives its precipitation from both westerly disturbances and summer monsoon system. In Gilgit River basin there are 585 glaciers and 605 glacier lakes, whereas, 8 potentially dangerous glacier lakes.

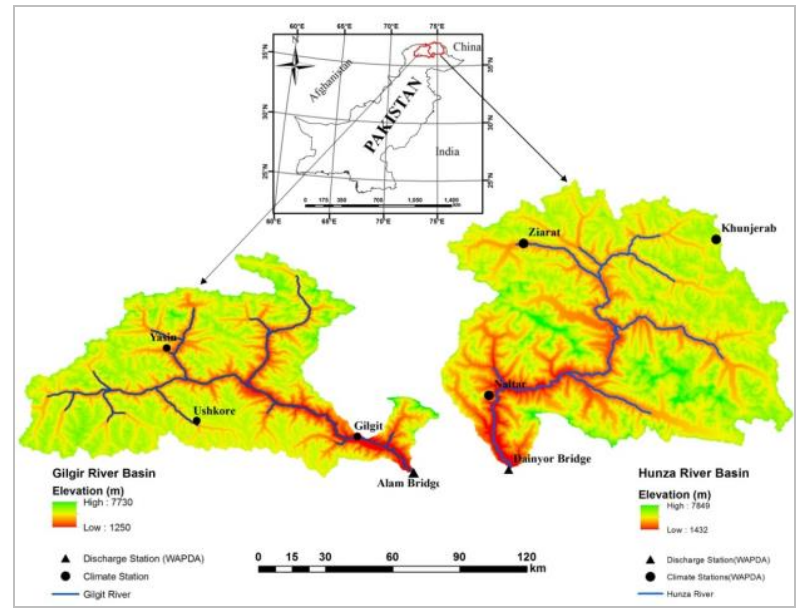

Figure 1. Study Area

The Hunza River basin with drainage area of $13,713 \mathrm{~km}^{2}$ (Fig. 1), geographically extends from $36.05^{\circ} \mathrm{N}, 74.04^{\circ} \mathrm{E}$ to $37.08^{\circ} \mathrm{N}$, $75.77^{\circ} \mathrm{E}$. It is situated in the high-altitude central Karakoram region, with a mean catchment elevation of $4,631 \mathrm{~m}$. Approximately $4,152 \mathrm{~km}^{2}$ of catchment area is glaciated. The elevation ranges from 1432 - 7849 m a.s.l. Shuttle Radar Topography Mission Digital Elevation Model (SRTM DEM 2000) of resolution 90m of U.S. National Aeronautics and Space Administration (NASA) is used to delineate the catchment boundaries of the study area. The total numbers of glaciers in basin are approximately 1,384. The clean glacier area is $3,673.04 \mathrm{~km}^{2}$ and the debris cover area is $479.56 \mathrm{~km}^{2}$. The snow cover area in the Hunza River basin varies from approximately $80 \%$ in winter to $30 \%$ in summer (Tahir, et al., 2011). The distribution of area versus elevation for both basins is shown in Figures 2 and 3.

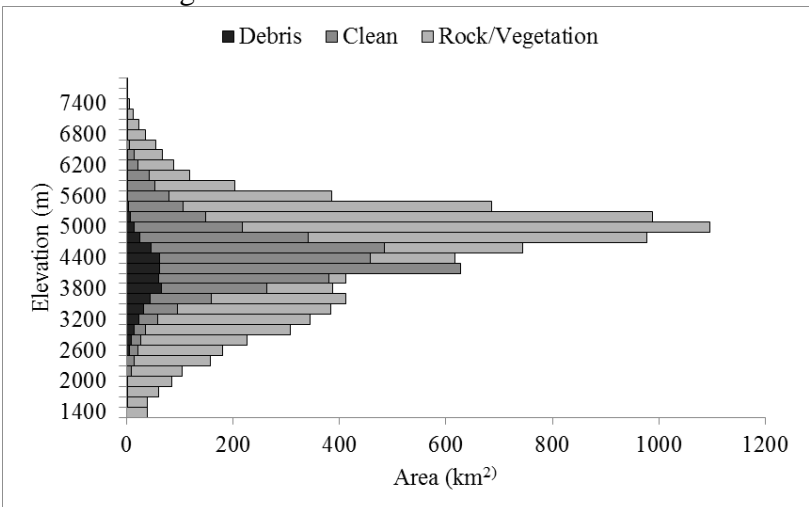

Figure 2. Hypsograph of Hunza River Basin

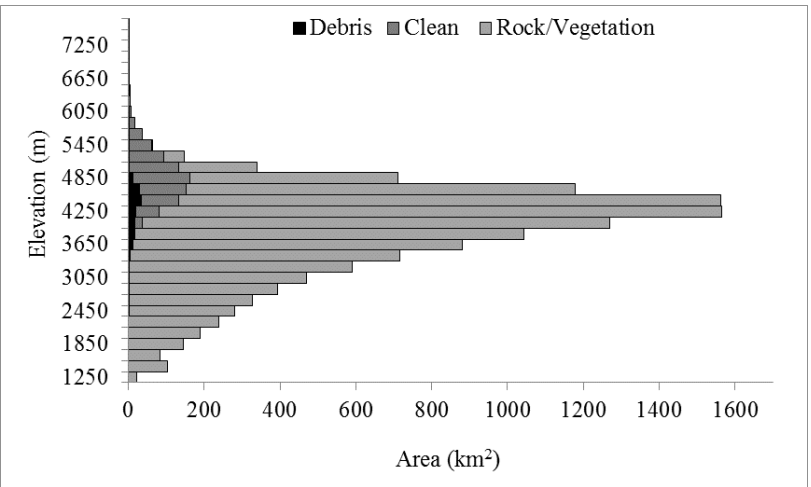

Figure 3. Hypsograph of Gilgit River Basin

\section{HYDROCLIMATIC DATA ANALYSIS}

Hydro-meteorological characteristics of each river have been determined through water yield calculation and basin analysis. Temperature and precipitation varies place to place due to altitudinal variation, monsoon path and topography. The Indus River and its tributaries rise in the sparsely populated glaciated mountains of western and central Asia. The Indus River itself contributes more than half the total flow and has a controlling storage at Tarbela Dam as the river emerges from the mountains (Hayley et al., 2005).

The UIB perceives contrasting hydro-meteorological regimes mainly because of the complex terrain of the HKH ranges and sophisticated interaction of prevailing regional circulations (Hasson et al., 2014a, 2015). The sparse (high and low altitude) meteorological network in such a difficult area neither covers fully its vertical nor its horizontal extents it may also be highly influenced by the complex terrain features and variability of the meteorological events. The hydrological regimes of Gilgit and Hunza as sub catchments of UIB due to its complex terrain, highly concentrated cryosphere and the form, magnitude and seasonality of moisture input associated with two distinct modes of prevailing large scale circulation; westerly disturbances and summer monsoon and river runoff is mainly dependent on these 
circulations. Two thirds of the precipitation in the Karakoram region is a result of westerly's influences and one third have a strong monsoon component (Hewitt, 2009).

WAPDA and PMD has maintained some automatic weather stations equipped with precipitation gauges as shown in (Fig. 1) at Gilgit, Yasin and Ushkor in Gilgit and Naltar, Ziarat and Khunjerab in Hunza basin located between elevation 1460 $4700 \mathrm{~m}$ a.s.l. The data from these stations are used for this study. Some year's precipitation data is missing in Yasin and Ushkor stations due to some problem in the gauges. Mean annual precipitation and temperature at different stations of both basins are presented in Table 1. Variations in temperature and precipitation at different climate stations are demonstrated in Figures $4 \& 5$ and $8 \& 9$ respectively. The decrease in precipitation at higher altitude is partly due to wind induced error especially in the case of snowfall where losses can be on average $10-50 \%$, regardless of the many gauges furnished with wind shields Sevruk (1985, 1989) and Forland et al. (1996).

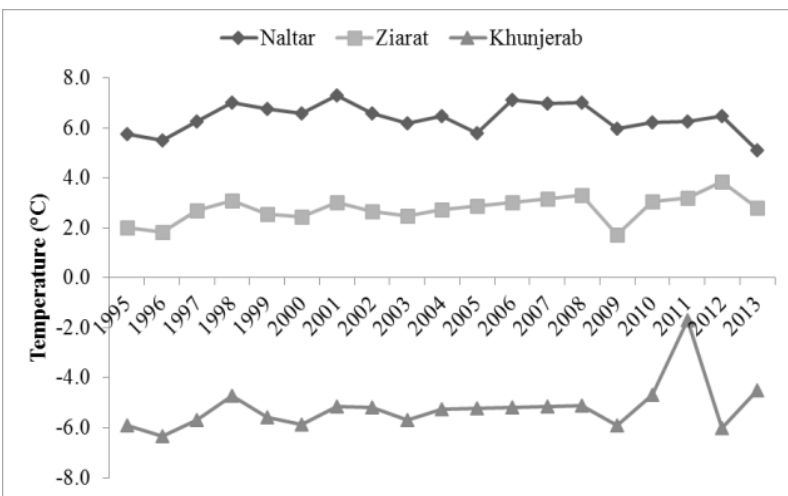

Figure 4. Variations in temperature at different climate stations (Hunza River Basin)

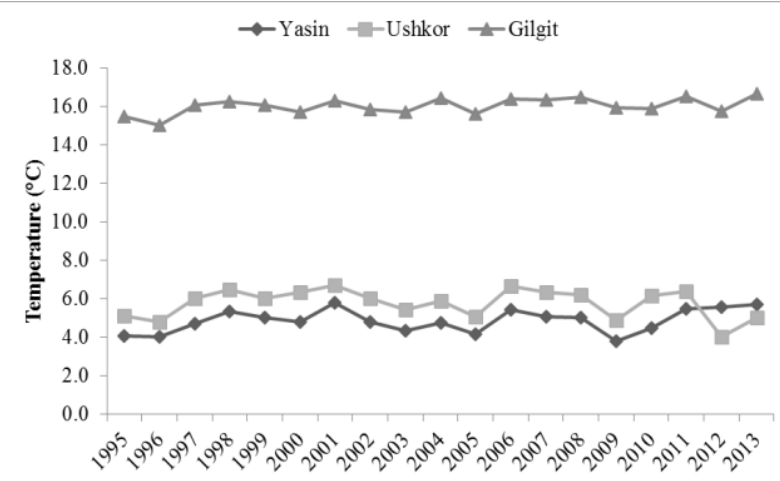

Figure 5. Variations in temperature at different climate stations (Gilgit River Basin)

Naltar is located in the south of the Hunza River basin and has the highest precipitation and the strongest influence of the monsoon (June, July, August [JJA]). The JJA variability is also the highest in Naltar, underlining the strong variability in monsoon strength. A non-parametric test Mann Kendall test which is a pragmatic choice that has been extensively adopted for hydro-climatic trend analysis has been done for studying the temporal trends of hydro-climatic series which shows no statistically significant trend in both temperature and precipitation data with $\mathrm{p}>0.05$ value. From this data analysis, it is observed that temperature is slightly decreasing at Naltar climate station (Hunza River basin) by $-0.0097^{\circ} \mathrm{C}$ yr- 1 on the other hand Yasin climate station (Gilgit basin) show an increasing trend by $0.036^{\circ} \mathrm{C}$ yr- 1 over a period of $1995-2013$ while precipitation shows increasing trend in both the stations with $0.3 \mathrm{~mm}$ yr-1 and $11.41 \mathrm{~mm}$ yr-1 respectively for the same time period (Fig. 6 and 7).

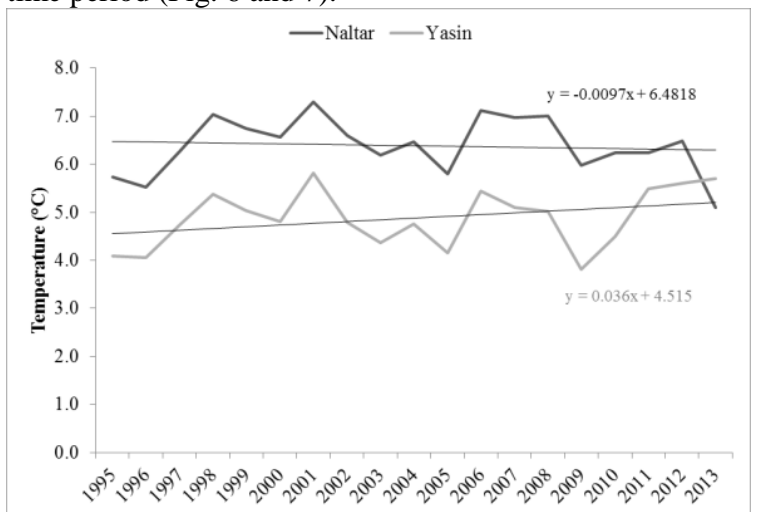

Figure 6. Annual Temperature trend at climate stations of both basins

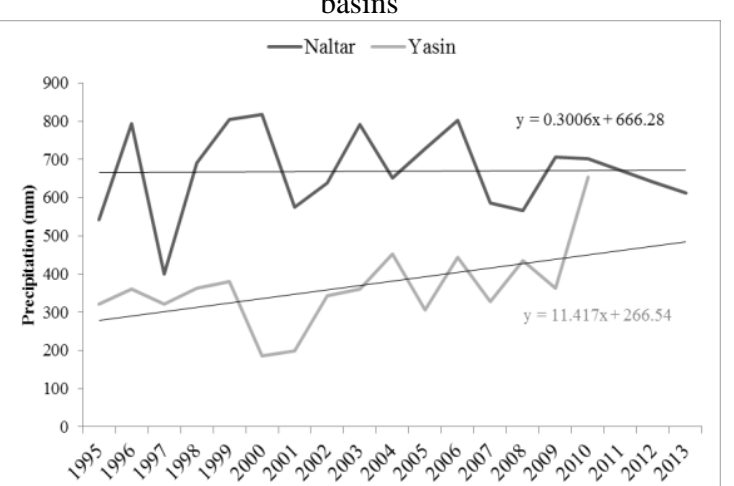

Figure 7. Annual Precipitation trend at climate stations of both basins

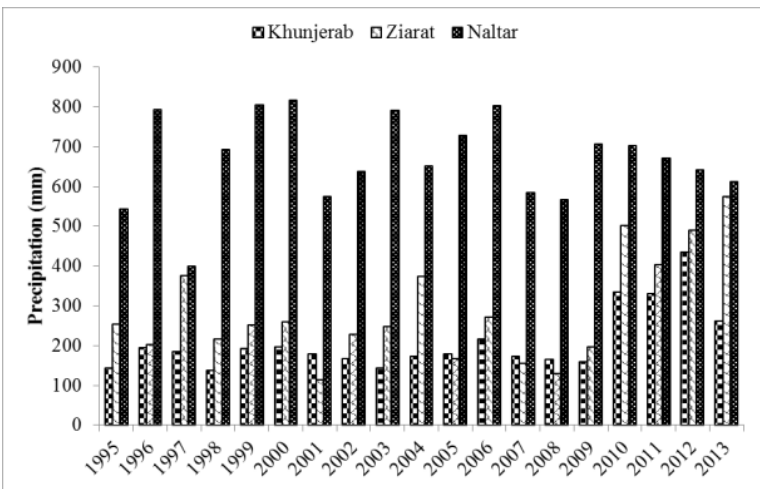

Figure 8. Variations in precipitation at different climate stations (Hunza River Basin)

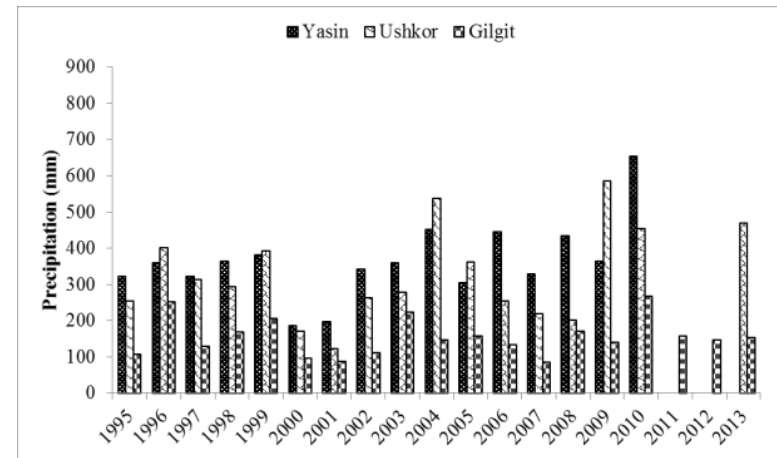

Figure 9. Variations in precipitation at different climate stations (Gilgit River Basin) 
According to the available data, mean annual runoff from Gilgit and Hunza rivers gauged at Alam bridge and Daniyour bridge, respectively are around $300 \mathrm{~m}^{3} / \mathrm{s}(1995-2013)$, and $323 \mathrm{~m}^{3} / \mathrm{s}$ (1966 - 2013) respectively, which is a large portion of the UIB mean annual runoff. Discharge is low from the month of January to April, start to pick up in May with the advent of summer and reach higher levels of discharge during July and August, continuing up to September, and then start to drop from October before the starting of winter and again become low during the months of November and December. The highest monthly average flow is in July at both discharge stations Fig.10. The discharge regime can be classified as glacial with maximum runoff in high flow period May to October and nonglacial with minimum runoff during the low flow period November to April.

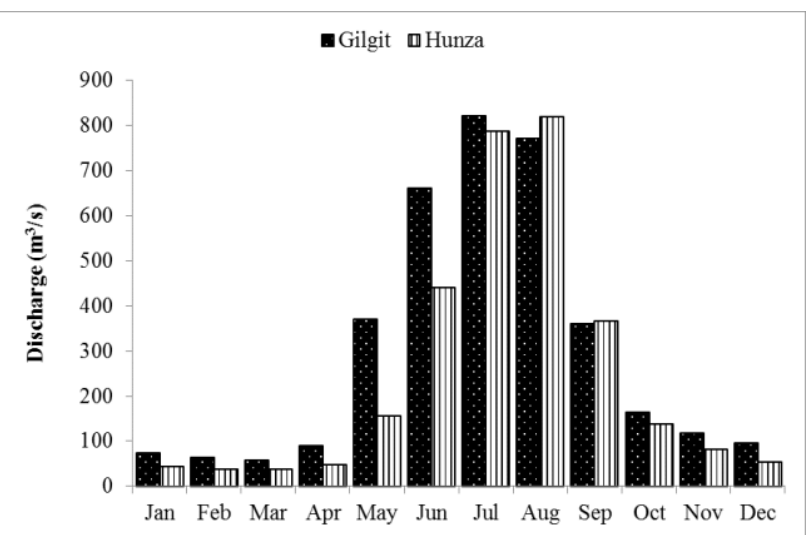

Figure 10. Monthly average flow at discharge stations of both basins

\section{METHODS}

The Modified Positive Degree Day Model (MPDDM) version 1.0 has been developed at the Himalayan Cryosphere, Climate and Disaster Research Center (HiCCDRC), Kathmandu University, Nepal in 2014. The MPDDM is based on the relation that the melting of snow or ice during any particular period is proportional to the positive degree-days linked by the positive degree day factor involving a simplification of complex process that are more properly described by the energy balance of the glacier surface and overlaying atmospheric boundary layer (Braithwaite and Olesen, 1989). This approach is appropriate in region with scarce data as it requires less input data and uses simple equation to estimate melt. In this model, the both basins are divided in to 33 elevation zones with $200 \mathrm{~m}$ bands. The model is forced by a combination of local meteorological observations. The local meteorological forcing data required by the model include air temperature, precipitation, at daily time step. For each elevation band, the air temperature and precipitation time series are interpolated according to its mean elevation using altitude-dependent lapse rates. The air temperature and precipitation are assumed to decrease with increasing altitude which was derived from observed temperature and precipitation data at the different stations (Table 2). Daily runoff data from the gauging stations located at the river outlet of the catchments (Fig. 1) are used to evaluate the model results. In each zone, daily snow and ice melt from the glacerized and glacier free areas is calculated using equation 1 .

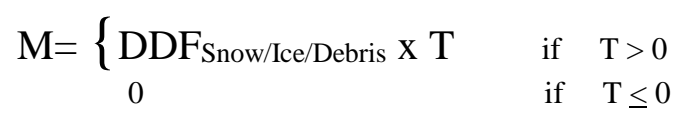

where, $\mathrm{M}$ is the snow or ice melts $(\mathrm{mm} / \mathrm{d}), \mathrm{T}$ is the air temperature $\left({ }^{\circ} \mathrm{C}\right)$ and DDF is the positive degree day factor for snow or ice $\left(\mathrm{mm} / \mathrm{d} /{ }^{\circ} \mathrm{C}\right)$.

A transition scheme outlined by Kayastha et al., 2000 is used to separate snow and rain in this study.

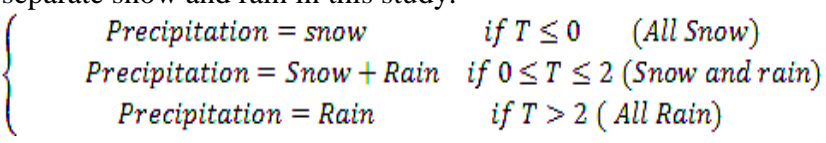

The snow and ice melt in precipitation contributing to runoff and the base from each elevation zone is calculated as given in equation 2. The runoff from all zones is summed to get the runoff from the entire basin $(\mathrm{Q})$ as given in equation 3. The flow chat of MPDDM is shown in Fig. 3.

$\mathrm{Q}_{\mathrm{z}}=\mathrm{Q}_{\mathrm{r}} \times \mathrm{C}_{\mathrm{r}}+\mathrm{Q}_{\mathrm{s}} \times \mathrm{C}_{\mathrm{s}}+\mathrm{Q}_{\mathrm{b}}$

$\mathrm{Q}=\sum_{z=1}^{z=n} \mathrm{Q}_{z}$

where, $\mathrm{Q}_{\mathrm{Z}}$ is the discharge $\left(\mathrm{m}^{3} / \mathrm{s}\right)$ from zone $\mathrm{Z}, \mathrm{Q}_{\mathrm{r}}$ and $\mathrm{Q}_{\mathrm{s}}$ are the discharge $\left(\mathrm{m}^{3} / \mathrm{s}\right)$ from direct precipitation and snow and ice melt, respectively, $\mathrm{C}$ is runoff coefficient with $\mathrm{C}_{\mathrm{r}}$ referring to rain and $\mathrm{C}_{\mathrm{s}}$ to snow and ice melt as mentioned in Martinec (1975) and $\mathrm{Q}_{\mathrm{b}}$ is the base flow $\left(\mathrm{m}^{3} / \mathrm{s}\right)$. The discharge $\mathrm{Q}$ is then routed to the basin outlet as per the recession equation 4 given by Martinec (1975).

$\mathrm{Q}_{\mathrm{n}}=\mathrm{Q}^{*}(1-\mathrm{k})+\mathrm{Q}_{\mathrm{n}-1}{ }^{*} \mathrm{k}$

where, $\mathrm{Q}_{\mathrm{n}}$ is the river discharge $\left(\mathrm{m}^{3} / \mathrm{s}\right)$ at the basin outlet on $\mathrm{nth}$ day and $\mathrm{k}$ is the recession coefficient.

\section{HYDROLOGIC SIMULATION}

The MPDDM was set up on two catchments of Upper Indus basin, Hunza and Gilgit river basins. Using a single criterion in the calibration and validation processes constrains the model parameters to fit certain characteristics of the observed data and neglects the remaining features. We adopt multiple criteria to assess the model performance: the Nash-Sutcliffe Efficiency (NSE), the relative mean error (RME) and volume difference (VD) (Table 3). NSE is sensitive to high peaks (Nash \& Sutcliffe, 1970); RME is for the relative error; and VD represents the overall difference between observation and simulation. Therefore, the combination of these three criteria can give a proper assessment of the model performance in runoff simulation.

\section{MODEL CALIBRATION AND VALIDATION}

\subsection{Hunza River Basin}

Model calibration involves constraining model parameters to obtain the best fit between the simulated results and the available observed data. These parameters are adjusted within ranges based on previously published values to minimize the difference between simulated and observed daily runoff for the period 2000-2013. The integrated model performance for simulating runoff is assessed by comparing simulated with observed daily runoff for both calibration (2000-2004) and validation (2008-2013) periods. In validation years three years (2005-2007) discharge data is missing, therefore we have not used these periods for validation. The results of calibration and validation periods for Hunza River basin are shown in Table 4. Graphically, simulated versus observed daily runoff are shown in Figures 11 and 12. The average observed discharge was $291.51 \mathrm{~m}^{3} / \mathrm{s}$ and $316.10 \mathrm{~m}^{3} / \mathrm{s}$ and simulated discharge is 
$279.59 \mathrm{~m}^{3} / \mathrm{s}$ and $272.51 \mathrm{~m}^{3} / \mathrm{s}$ for calibration and validation period, respectively.

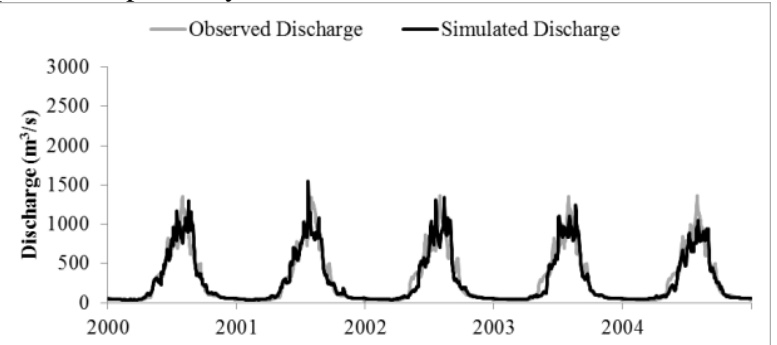

Figure 11. Calibration of MPDDM Hunza River Basin

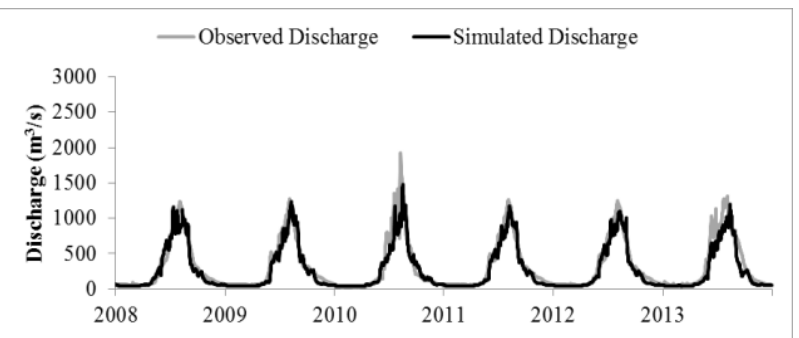

Figure 12. Validation of MPDDM Hunza River Basin

\section{2}

Gilgit River Basin

The model was calibrated from 1999 to 2005 , and validated from 2006 to 2010 at a daily time step. The results of calibration and validation periods for Gilgit River basin are shown in Table 5. For graphical representation, the observed and simulated discharge in calibration and validation period is presented in Figures 13 and 14. The average observed discharge was $298.18 \mathrm{~m}^{3} / \mathrm{s}$ and $316.60 \mathrm{~m}^{3} / \mathrm{s}$ and simulated discharge is $286.99 \mathrm{~m}^{3} / \mathrm{s}$ and $304.07 \mathrm{~m}^{3} / \mathrm{s}$ for calibration and validation period respectively.

Calibration and validation results clearly shows that the model can efficiently simulate hydrologic response of the Hunza and Gilgit River basins and give a good fit of the low flow as well as high flow using the optimal parameter sets (Table 6), with a rating of 'very good' on the scale of Moriasi et al. (2007), except some sudden peaks due to some extreme events like (cloud burst, GLOF, eruption of ponds and etc.) during monsoon period which is common in hydrological modeling but the uncertainty of the results cannot be ignored. The sources of the uncertainty are data used in the calibration and validation. Among the observed data of precipitation, temperature and discharge, the precipitation data are expected to be the largest source of uncertainty because most stations are located at lower elevations, while information about precipitation at higher elevations (above $5000 \mathrm{~m}$ a.s.l) is missing. Additionally in this study, a degree-day method for snow melting was used and the snow cover area is not updated or modelled. By doing this, there is unlimited snow available for melting, which might not realistic in a long term simulation and may lead to high estimation of water from rain-base flow as compared to snowice melt.

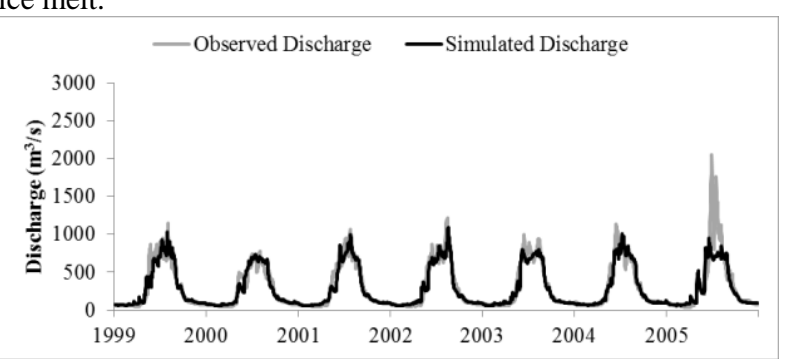

Figure 13. Calibration of MPDDM Gilgit River Basin

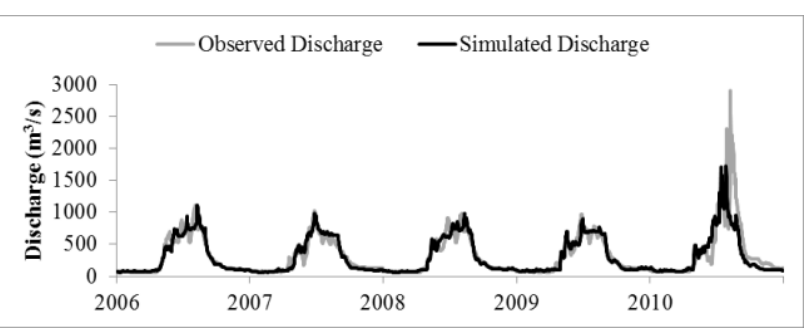

Figure 14. Calibration of MPDDM Gilgit River Basin

\section{RUNOFF COMPONENTS}

We calculated variations in runoff and its components in the both catchments of UIB using observed meteorological data. In Hunza River basin a large fraction of runoff is from snow-ice melt $38.73 \%$. Irrespective of glacier runoff, base flow contributes $50.84 \%$ of total runoff, rainfall runoff is $10.43 \%$. On the other hand the contributions of different components of runoff like snow-ice melt, base flow and rainfall in Gilgit River basin are $26.58 \%, 61.11 \%$ and $0.12 \%$ respectively. Base flow is the technical name for the dry weather flow and much of the wet weather flow in a stream or river. River base flow results from ground water seeping into riverbanks or the riverbed. The flow may be significant enough to allow the stream to flow year round (i.e., perennial or permanent stream). Without base flow recharge from ground water to streams and rivers, many would not carry a flow of water except during storms. Streams that flow only periodically in response to rainstorms or seasonal snowmelt events are known as ephemeral or intermittent streams (American Ground Water Trust, 2003). In an ideal basin the geologic material are of uniform permeability and the steam has excellent hydraulic continuity with the nearby aquifer rarely if ever is this situation come across in nature most all basins have complex geology and streams draining such basins may have incomplete hydraulic continuity with the underlying aquifers in many cases more than one aquifer may be contributing water to the streams (Ferris et al., 1962). According to genetic components of stream flow for the Hindu Kush Karakoram, Pamir and Tien Shan mountains established by (Dreyer et al., 1982) rivers are fed by groundwater from November to February. Snowmelt begins in the lower parts of basin in March, and groundwater discharge increase to maximum in July - August, until September Rivers are fed by groundwater, ice melt, snowmelt and precipitation. Snowmelt ceases by October in high mountains and rivers are fed solely by groundwater. The method is based on regular changes in stream flow structure during the year.

Monthly variation in the magnitude of the contribution of each runoff component to the total runoff and its intra-annual distribution are presented for the period 1999-2013 in Figures 15 and 16. According to our estimation the mean annual glacier runoff in Hunza and Gilgit River basin are observed between May - October $47.71 \%$ and $33.2 \%$, respectively, the fraction of glacier runoff approaches zero during the winter months, and runoff from the glacier-free zone of the catchment is a larger component of total runoff. With increasing temperature, the contribution from glacier runoff begins to increase and reaches maximum in May $(\approx 65 \%)$ and is also significant during the other summer months $(\approx 40-55 \%)$ in Hunza River basin. On the other hand glacier runoff is maximum in May $(\approx 50 \%)$ and $\approx 20-45 \%$ in other summer months in Gilgit River basin. Rainfall is the largest contributor in July and August. The melting of glaciers along with the more precipitation fall as rain is likely to cause heavy flooding and Hunza and Gilgit River 
basin is susceptible to floods in monsoon as recorded in 2005 and 2010 .

$$
\text { Base flow gRain } \square \text { Snow \& Ice }
$$

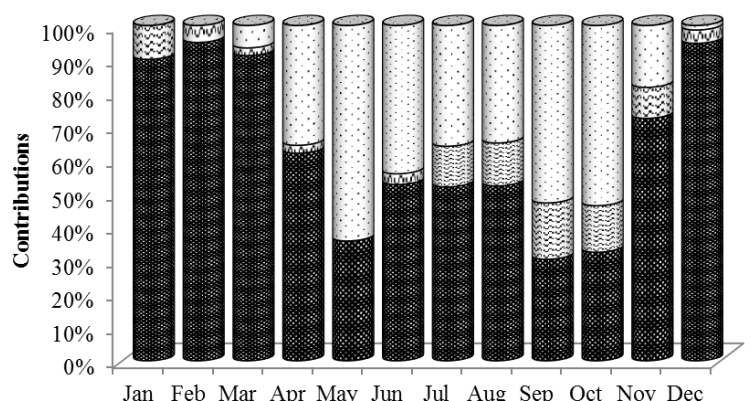

Figure 15. Monthly contribution of runoff components from Hunza River Basin

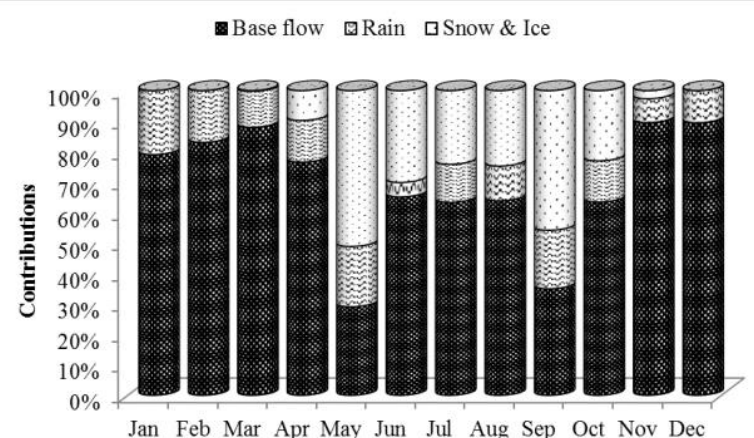

Figure 16. Monthly contribution of runoff components from Gilgit River Basin

Table.1 Mean annual precipitation and temperature at different

\begin{tabular}{|l|l|l|c|c|}
\hline \multicolumn{5}{c}{ Stations of both basins } \\
\hline Station & $\begin{array}{c}\text { Elevation } \\
(\mathbf{m} \text { a.s.l) }\end{array}$ & Period & $\begin{array}{c}\text { Mean Annual } \\
\text { Temperature }\left({ }^{\circ} \mathbf{C}\right)\end{array}$ & $\begin{array}{c}\text { Mean Annual } \\
\text { Precipitation (mm) }\end{array}$ \\
\hline Gilgit & 1460 & $1995-2013$ & 16.0 & 155 \\
\hline Naltar & 2898 & $1995-2013$ & 6.0 & 669 \\
\hline Ushkor & 3051 & $1995-2013$ & 6.0 & 394 \\
\hline Yasin & 3280 & $1995-2013$ & 5.0 & 364 \\
\hline Ziarat & 3668 & $1995-2013$ & 3.0 & 285 \\
\hline Khunjerab & 4730 & $1995-2013$ & -5.0 & 209 \\
\hline
\end{tabular}

Table 2. Details of climatic and Discharge stations, their coordinates, data period, and sources of data.

\begin{tabular}{|c|c|c|c|c|c|c|c|}
\hline \multirow{2}{*}{$\begin{array}{l}\text { Sr. } \\
\text { No. }\end{array}$} & \multirow[t]{2}{*}{ Station } & \multirow[t]{2}{*}{ Basin } & \multirow[t]{2}{*}{ Elevation $(\mathbf{m})$} & \multicolumn{2}{|c|}{ Coordinates } & \multirow{2}{*}{$\begin{array}{l}\text { Period of } \\
\text { Record }\end{array}$} & \multirow[t]{2}{*}{ Source } \\
\hline & & & & Lat & Long & & \\
\hline \multicolumn{8}{|c|}{ Climate Stations } \\
\hline 1 & Naltar & & 2898 & 36.168 & 74.175 & 1995-2013 & WAPDA \\
\hline 2 & Ziarat & Hunza & 3668 & 36.829 & 74.418 & 1995-2013 & WAPDA \\
\hline 3 & Khunjerab & & 4730 & 36.812 & 75.332 & 1995-2013 & WAPDA \\
\hline 4 & Yasin & & 3280 & 36.451 & 73.294 & 1995-2013 & WAPDA \\
\hline 5 & Ushkor & Gilgit & 3051 & 36.027 & 73.415 & 1995-2013 & WAPDA \\
\hline 6 & Gilgit & & 1460 & 35.921 & 74.327 & 2000-2013 & PMD \\
\hline \multicolumn{8}{|c|}{ Discharge Stations } \\
\hline 1 & Daniyour $\mathrm{Br}$. & Hunza & 1450 & 35.56 & 74.23 & $1960-2013$ & WAPDA \\
\hline 2 & Alam Br. & Gilgit & 1430 & 35.56 & 74.19 & 1995-2013 & WAPDA \\
\hline
\end{tabular}

Table 3. Model performance assessment criteria and their

\begin{tabular}{lcll}
\multicolumn{4}{c}{ corresponding formulation } \\
\hline Criteria & Formula & Value Range & Perfect Value \\
\hline NSE & $1-\frac{\sum_{i=1}^{n}\left(O_{i}-S_{i}\right)^{2}}{\sum_{i=1}^{n}\left(O_{i}-\bar{O}_{i}\right)^{2}}$ & $-\infty, 1$ & 1 \\
VD & $\frac{V_{R}-V_{R}^{\prime}}{V_{R}} * 100$ & $\begin{array}{l}\text { Least volume difference } \\
\text { indicate the good fit of } \\
\text { model }\end{array}$ & \\
RME & $\frac{\sum_{i=1}^{n}\left(S_{i}-O_{i}\right)}{\sum_{i=1}^{n} O_{i}}$ & $-\infty,+\infty$ & 0
\end{tabular}

Where $\mathrm{Oi}$ and $\mathrm{Si}$ are the observed and simulated flow, respectively; $i$ is the time series index; $n$ is the total number of time steps; VR is measured runoff volume; VR' is simulated runoff volume.

Table 4. Model efficiency of calibration and validation periods

\begin{tabular}{llll}
\multicolumn{4}{c}{ On Hunza River Basin } \\
\hline Period & NSE & VD & RME \\
\hline Calibration & 0.88 & $4.09 \%$ & -0.04 \\
Validation & 0.89 & $13.79 \%$ & -0.13 \\
& & & \\
\hline
\end{tabular}

Table 5. Model efficiency of calibration and validation periods

\begin{tabular}{llcc}
\multicolumn{4}{l}{ on Gilgit River Basin } \\
\hline Period & NSE & VD & RME \\
\hline Calibration & 0.85 & $3.75 \%$ & -0.04 \\
Validation & 0.78 & $3.96 \%$ & -0.04 \\
\hline
\end{tabular}

Table 6. List of calibrated parameters used in MPDDM

\begin{tabular}{|c|c|c|}
\hline Parameters & Description & Values \\
\hline $\mathbf{k}_{\mathrm{s}}$ & $\begin{array}{l}\text { Degree day factor for snow ablation } \\
\text { (Bocchiola, et al., 2011) }\end{array}$ & $\begin{array}{l}5.0-6.0 \mathrm{~mm} /{ }^{\circ} \mathrm{C} / \text { day }(\mathrm{Jan}-\mathrm{Apr}) \\
6.0-8.0 \mathrm{~mm} /{ }^{\circ} \mathrm{C} / \text { day }(\text { May }-\mathrm{Sep}) \\
6.5-7.0 \mathrm{~mm} /{ }^{\circ} \mathrm{C} / \text { day }(\mathrm{Oct}-\mathrm{Dec})\end{array}$ \\
\hline $\mathbf{k}_{\mathbf{i}}$ & $\begin{array}{l}\text { Degree day factor for ice ablation } \\
\text { (Bocchiola, et al., 2011) }\end{array}$ & $\begin{array}{l}6.0-8.0 \mathrm{~mm} /{ }^{\circ} \mathrm{C} / \text { day }(\mathrm{Jan}-\mathrm{Apr}) \\
6.0-9.0 \mathrm{~mm} /{ }^{\circ} \mathrm{C} / \text { day }(\text { May }-\mathrm{Sep}) \\
7.5-8.5 \mathrm{~mm} /{ }^{\circ} \mathrm{C} / \text { day }(\text { Oct }- \text { Dec })\end{array}$ \\
\hline $\mathbf{k}_{\mathbf{d}}$ & $\begin{array}{l}\text { Degree day factor for debris covered } \\
\text { ice (Mihalcea, et al., 2006) }\end{array}$ & $4-6 \mathrm{~mm} /{ }^{\circ} \mathrm{C} / \mathrm{day}$ \\
\hline$\Gamma$ & Temperature Lapse Rate & $0.48-0.76^{\circ} \mathrm{C} / 100 \mathrm{~m}$ \\
\hline PG & Precipitation Gradient & $0.25-1$ \\
\hline $\mathrm{Cr}$ & Coefficient of Rain & $0.08-0.5$ \\
\hline Cs & $\begin{array}{l}\text { Coefficient of Snow. } \\
\text { (Tahir, et al., 2011) }\end{array}$ & $0.1-0.40$ \\
\hline $\mathbf{X}$ & Constant for Recession Coefficient & 0.97 \\
\hline $\mathbf{Y}$ & & 0.04 \\
\hline
\end{tabular}

\section{CONCLUSION}

The mountains region of UIB is a key source of water for Pakistan and delivers the main water source for the IBIS, one of the world's largest assimilated irrigation networks. The River Indus is nourished by an amalgamation of melt water from seasonal and permanent snow fields and glaciers, and runoff from rainfall both during the winter and monsoon season. To simulate the runoff and its contribution components in Upper 
Indus, the MPDDM was used to identify the runoff proportions from rain and base flow, snow-ice melt in two catchments of Upper Indus basin: Hunza River basin, and Gilgit River basin. The results show that the MPDDM is able to give rational assessment of runoff on these two catchments. The hydrological components differ between both basins and these affect the flow of Indus River and the water resource use in the lower Indus. For the Gilgit river basin, the largest contributor to runoff is rain and base flow, whereas melting of snow-ice is markedly dominant in the Hunza River basin. The variation of hydrological components within the basin was due to the elevation range and the distribution of areas within each elevation band in the catchment, temperature variations, permanent snowfields and the glacierized proportion. The more precipitation that falls as rain is likely to raise the high flow and glacier retreating is likely to reduce the base flow, which possibly leads to more droughts and floods. In summary, these two study basins are vulnerable to climate change. The model performances can be enhanced by using some other global climate data and emissions scenarios to assess the potential impacts of climate change on the hydrology of whole Upper Indus basin as a macro scale model.

\section{ACKNOWLEDGEMENTS}

We acknowledge support from the Contribution to High Asia Runoff from Ice and Snow (CHARIS) Project, University of Colorado, Boulder, USA funded by the United States Agency for International Development (USAID).We thank the project partners for their help in carrying out this study, including: the Himalayan Cryosphere, Climate and Disaster Research Center (HiCCDRC), the Department of Environmental Science and Engineering, School of Science, Kathmandu University, Glacier Monitoring Research Center (GMRC); Water \& Power Development Authority (WAPDA) Government of Pakistan.

\section{REFERENCES}

Archer, D.R., (2003). Contrasting hydrological regimes in the Upper Indus Basin. J. Hydrol. 274, 198-210.

American Ground Water Trust (2003). Groundwater and river flow. THE AMERICAN WELL OWNER, 2003, Number 3

Bajracharya, SR; Shrestha, B.,(eds) 2011. The status of Glaciers in Hindu Kush-Himalayan region. Kathmandu: ICIMOD.

Braithwaite, R. J., and Olesen, O.B., (1989): Calculation of glacier ablation from air temperature, West Greenland. In Glacier fluctuations and climate change. Ed. Oerleamas, J., Kluwer Academic Publishers, Dordrecht, 219-233.

Dahlke, H. E., Lyon, S. W., Jansson, P., Karlin, T. \& Rosqvist, G. (2013) Isotopic investigation of runoff generation in a glacierized catchment in northern Sweden. Hydrological Processes. doi: 10.1002/hyp.9668.

Dreyer, N. N., Nikolayeva, G. M., and Tsigelnaya, I.D., (1982) Maps of streamflow resources of some high mountain areas in Asia and North America Hydrological Aspects of Alpine and High Mountain Areas (Proceedings of the Exeter Symposium, July 1982). IAHS Publ. no. 138.
Ferris, J.G., and others, 1962, theory of aquifer tests: U. S. Geol. Survey Water suppl Paper 1936E, p.99-101.

Forland, E.J. et al., 1996. Manual for operational correction of Nordic precipitation data.24/96, DNMI, P.O. Box 43, Blindern, Oslo, Norway.

Fowler, H. J. and Archer, D. R.: Hydro-climatological variability in the Upper Indus Basin and implications for water resources, in: IAHS Publ. 295, Regional Hydrological Impacts of Climatic Change - Impact Assessment and Decision Making, Proceedings of symposium S6, Seventh IAHS Scientific Assembly, Foz do Iguaçu, Brazil, 2005

Gardelle, J., Berthier, E., Arnaud, Y., and Kääb, A.: Regionwide glacier mass balances over the Pamir-KarakoramHimalaya during 1999-2011, The Cryosphere, 7, 1263-1286, doi:10.5194/tc-7-1263-2013, 2013.

Hagg, W., Braun, L. N., Kuhn, M. \& Nesgaard, T. I. (2007) Modelling of hydrological response to climate change in glacierized Central Asian catchments. Journal of Hydrology 332(1-2), 40-53.

Hasson, S., Lucarini, V., Pascale, S., and Böhner, J.: Seasonality of the hydrological cycle in major South and Southeast Asian river basins as simulated by PCMDI/CMIP3 experiments, Earth Syst. Dynam., 5, 67-87, doi:10.5194/esd-567-2014, 2014a.

Hasson, S., Pascale, S., Lucarini, V., and Böhner, J. (2015): Seasonal cycle of precipitation over Major River Basins in South and Southeast Asia: a review of the CMIP5 climate models data for present climate and future climate projections, J. Atmos. Res.

Hayley J. Fowler and David R. Archer," Hydro-climatological variability in the Upper Indus Basin and implications for water resources", Regional Hydrological Impacts of Climatic ChangeImpact Assessment and Decision Making ,Proceedings of symposium S6 held during the Seventh IAHS Scientific Assembly at Foz do Iguaçu, Brazil, April 2005, IAHS Publ. 295 (2005).

Hewitt, K.: The Karakoram anomaly? Glacier expansion and the "elevation effect", Karakoram Himalaya, Mt. Res. Dev., 25, 332-340, 2005.

Hewitt, K (2009). Glacier change and Himalayan cryosphere. Lecture presented at global change impact study center. Islamabad, Pakistan.

Hewitt, K.: Glacier change, concentration, and elevation e_ects in the Karakoram Himalaya, Upper Indus Basin, Mt. Res. Dev., 31, 188-200, doi:10.1659/MRD-JOURNAL-D-11-00020.1, 2011.

Hussain, M., Farinotti, D., Bauder, A. \& Funk, M. (2008) Modelling runoff from highly glacierized alpine drainage basins in a changing climate. Hydrological Processes 22(19), 38883902 . 
Kaab, A., Berthier, E., Nuth, C., Gardelle, J., Arnaud, Y. Contrasting patterns of early twenty-first-century glacier mass change in the Himalayas. Nature 488, 495-498 (2012).

Kaser, G., Großhauser, M. \& Marzeion, B. (2010) Contribution potential of glaciers to water availability in different climate regimes. In: National Academy of Sciences of the United States of America (ed. by R. G. Barry), 20223-20227.

Kayastha, R. B., Ageta, Y., and Nakawo, M., (2000). Positive Degree-day factors for ablation on glaciers in the Napalese Himalayas: case study on Glacier AX010 in Shorong Himal Nepal. Bulletin of glaciological research, 17. 1-10.

Koboltschnig, G. R., Schöner, W., Zappa, M., Kroisleitner, C. \& Holzmann, H. (2008) Runoff modelling of the glacierized Alpine Upper Salzach basin (Austria): Multi-criteria result validation. Hydrological Processes 22(19), 3950-3964.

Kotliakov, V. M. (1996) Variations of Snow and Ice in the past and at present on a Global and Regional Scale. Citeseer.

Kumar, V., Singh, P. \& Singh, V. (2007) Snow and glacier melt contribution in the Beas River at Pandoh Dam, Himachal Pradesh, India. Hydrological Sciences Journal 52(2), 376-388.

Martinec, J., (1975). Snowmelt-runoff model for stream flow forecasts. Nordic Hydrology, 6(3), 145-154. Doi:10.2166/nh. 1975.010

Moriasi D.N., Arnold, J., Liew, M.W., Bingner, R.L., Harmel, R.D., Veith, T.L., 2007. Model evaluation guidelines for systematic quantification of accuracy in watershed simulations. Trans. Am. Soc. Agric. Biol. Eng., 50(3), 885-900

Nash, J. E. \& Sutcliffe, J. V. (1970) River flow forecasting through conceptual models part $\mathrm{I}-\mathrm{A}$ discussion of principles. Journal of Hydrology 10(3), 282-290.

Naz, B., Frans, C., Clarke, G., Burns, P. \& Lettenmaier, D. (2013) Modeling the effect of glacier recession on streamflow response using a coupled glacio-hydrological model. Hydrology and Earth System Sciences Discussions 10(4), 5013-5056.

Nepal, S., Krause, P., Flügel, W.A., Fink, M. \& Fischer, C. (2013) Understanding the hydrological system dynamics of a glaciated alpine catchment in the Himalayan region using the J2000 hydrological model. Hydrological Processes doi: 10.1002/hyp.9627.

Prasch, M. (2010) Distributed process oriented modelling of the future impact of glacier melt water on runoff in the Lhasa River Basin in Tibet. Doctor, Ludwig-Maximilians-University of Munich, Germany.

Salik, K. M., Jahangir, S., Zahdi, W. Z., and Hasson, S. (2015.): Climate change vulnerability and adaptation options for the coastal communities of Pakistan, Ocean Coast. Manage.

Sevruk, B., 1985. Correction of precipitation measurements, Workshop on the Correction of Precipitation Measurements. WMO/IAHS/ETH, Zurich, Switzerland, pp. 13-23.
Sevruk, B., 1989. Reliability of precipitation measurement, International Workshop on Precipitation Measurement. WMO Tech. Document, pp. 13-19.

Tahir, A.A., Chevallier, P., Arnaud, Y., Ahmad, B., 2011. Snow cover dynamics and hydrological regime of the Hunza River basin, Karakoram Range, Northern Pakistan. Hydrology and Earth System Sciences 15(7):2275-2290. www.hydrolearthsyst-sci.net/15/2275/2011/; accessed 4 August 2011.http://dx.doi.org/10.5194/hess-15-2275-2011.

Thayyen, R. J., Gergan, J. T. \& Dobhal, D. P. (2005) Monsoonal control on glacier discharge and hydrograph characteristics, a case study of Dokriani Glacier, Garhwal Himalaya, India. Journal of Hydrology 306(1-4), 37-49. 